\title{
Economic losses due to bovine brucellosis in Brazil ${ }^{1}$
}

\author{
Renato L. Santos ${ }^{2 *}$, Telma M. Martins², Álan M. Borges² and Tatiane A. Paixão ${ }^{3}$ \\ ABSTRACT.- Santos R.L., Martins T.M., Borges A.M. \& Paixão T.A. 2013. Economic losses \\ due to bovine brucellosis in Brazil. Pesquisa Veterinária Brasileira 33(6):759-764. De- \\ partamento de Clínica e Cirurgia Veterinárias, Escola de Veterinária, Universidade Federal \\ de Minas Gerais, Avenida Antônio Carlos 6627, Pampulha, Belo Horizonte, MG 31270-901, \\ Brazil.E-mail: rsantos@vet.ufmg.br \\ Brucellosis is an important zoonosis of worldwide distribution. Reliable epidemiolo- \\ gic brucellosis data covering approximately $90 \%$ of the cattle population in Brazil have \\ been recently published. Therefore, considering the scarcity of information regarding the \\ economic impact of bovine brucellosis in Brazil, the goal of this study was to estimate eco- \\ nomic impact of brucellosis on the Brazilian cattle industry. Several parameters including \\ abortion and perinatal mortality rates, temporary infertility, replacement costs, mortality, \\ veterinary costs, milk and meat losses were considered in the model. Bovine brucellosis \\ in Brazil results in an estimated loss of $\mathrm{R} \$ 420,12$ or $\mathrm{R} \$ 226,47$ for each individual dairy \\ or beef infected female above 24 months of age, respectively. The total estimated losses in \\ Brazil attributed to bovine brucellosis were estimated to be approximately R $\$ 892$ million \\ (equivalent to about 448 million American dollars). Every 1\% increase or decrease in pre- \\ valence is expected to increase or decrease the economic burden of brucellosis in approxi- \\ mately 155 million Reais.
}

INDEX TERMS: Brucella abortus, brucellosis, cattle, economic losses.

RESUMO.- [Perdas econômicas devidas à brucelose bovina no Brasil.] A brucelose é uma zoonose de importância mundial. Recentes dados epidemiológicos dessa doença foram obtidos por meio de estudos que abrangeram em torno de $90 \%$ do rebanho bovino do Brasil. Observa-se escassez de informações sobre o impacto econômico causado pela brucelose bovina, portanto, o objetivo do presente estudo foi estimar as perdas econômicas na pecuária brasileira. Gastos relacionados com as ocorrências de abortos, natimortos, subfertilidade, descartes involuntários, mortalidade, intervenções veterinárias, diminuição da produção de leite e de carne, foram considerados nos cálculos. As perdas devidas à brucelose bovina no Brasil foram estimadas em $R \$ 420,12$ ou $R \$ 226,47$ para cada fêmea infectada acima de 24 meses de idade em rebanhos de leite

\footnotetext{
${ }^{1}$ Received on March 5, 2013.

Accepted for publication on April 18, 2013.

${ }^{2}$ Departamento de Clínica e Cirurgia Veterinárias, Escola de Veterinária, Universidade Federal de Minas Gerais (UFMG), Avenida Antônio Carlos 6627, Pampulha, Belo Horizonte, MG 31270-901, Brazil. *Corresponding author: rsantos@vet.ufmg.br

${ }^{3}$ Departamento de Patologia Geral, Instituto de Ciências Biológicas, UFMG, Belo Horizonte, MG.
}

ou corte, respectivamente. 0 prejuízo total estimado foi de, aproximadamente, $\mathrm{R} \$ 892$ milhões (equivalentes a $\$ 448$ milhões de dólares americanos). A cada $1 \%$ de variação na prevalência, estima-se a variação de 155 milhões de reais no custo da brucelose bovina no Brasil.

TERMOS DE INDEXAÇÃO: Brucella abortus, brucelose, bovino, perdas econômicas.

\section{INTRODUCTION}

Brucellosis is an important zoonosis of worldwide distribution. Clinical manifestations of brucellosis are determined by the combination of pathogen and host species since Brucella spp. have distinct host preferences (Xavier et al. 2009a, Poester et al. 2013). Most of Brucella species are capable of infecting humans, with B. melitensis having the highest zoonotic potential (Young 1995) followed by B. suis and $B$. abortus. In cattle, brucellosis is mostly caused by $B$. abortus infection (Poester et al. 2013), and it is characterized by abortions during the last trimester of gestation, perinatal mortality, and infertility, whereas bulls can develop orchitis (Carvalho Neta et al. 2010, Poester et al. 2013). Importantly high bacterial loads are present in aborted fetuses and fetal membranes (Xavier et al. 2009b), favoring 
transmission within the herd. In addition, B. abortus infection is associated with interstitial, often subclinical, mastitis that is associated with shedding of the organism in the milk (Xavier et al. 2009b), which poses a health hazard for human consumption of unpasteurized dairy products.

The Brazilian National Program for Control and Eradication of Brucellosis and Tuberculosis has recently provided detailed epidemiological data covering most of the cattle population in the country (Poester et al. 2009), including the states of Bahia (Alves et al. 2009), the Federal District (Gonçalves et al. 2009a), Espírito Santo (Azevedo et al. 2009), Goiás (Rocha et al. 2009), Minas Gerais (Gonçalves et al. 2009b), Mato Grosso do Sul (Chate et al. 2009), Mato Grosso (Negreiros et al. 2009), Paraná (Dias et al. 2009b), Rio de Janeiro (Klein-Gunnewiek et al. 2009), Rondônia (Villar et al. 2009), Rio Grande do Sul (Marvulo et al. 2009), Santa Catarina (Sikusawa et al. 2009), Sergipe (Silva et al. 2009), São Paulo (Dias et al. 2009a) e Tocantins (Ogata et al. 2009). In addition, recent epidemiological data from the State of Pará has been included in the present study (Minervino et al. 2011). Together these studies provide epidemiological data covering approximately $90 \%$ of the cattle population in Brazil.

Considering the scarcity of information regarding the economic impact of bovine brucellosis in Brazil, with only outdated information available (Brasil 1971), the goal of this study was to estimate economic impact of brucellosis on the Brazilian cattle industry.

\section{MATERIALS AND METHODS}

\section{Data sources}

Epidemiological data were mostly from prevalence studies from the Brazilian National Program for the Control and Eradication of Brucellosis and Tuberculosis (Poester et al. 2009), with the exception of the State of Pará (Minervino et al. 2011). Data regarding population and categories of cattle in all Brazilian States were obtained from the Instituto Brasileiro de Geografia e Estatística (IBGE 2011). Data regarding Gross Domestic Product (GDP) were obtained from the Centro de Estudos Avançados em Economia Aplicada (CEPEA/ESALQ 2013) and IBGE (2012). Tables 1 and 2 summarize the raw data employed in this study.

\section{Parameters for calculating economic losses}

For the purpose of this study, serologically positive cattle were considered infected. Reproductive and productive parameters were based on previously published indicators (Bernués et al. 1997) with minor adaptations as follows: (i) 15\% incidence of abortions in infected heifers and cows; (ii) an average of 2 months of temporary infertility for each infected cow and heifer, considering that $20 \%$ of cows that aborts become sterile, which has been included in the calculation of replacement costs; (iii) an incidence rate of perinatal mortality of $10 \%$ for calves born from infected cows or heifers; (iv) $15 \%$ loss of the total milk yield of infected cows; (v) $5 \%$ loss in meat production by infected cows; (vi) $1 \%$ mortality risk for infected cows that aborted (i.e. $0.15 \%$ of infected cows and heifers); (vii) increase in the rate of replacement corresponding to $15 \%$ of the infected cows and heifers (the cost was calculated based on the difference of the value received by a slaughtered cow under sanitary conditions and the cost of a replacement cow); and (viii) replacement costs of infected bulls, considering roughly half of the seroprevalence of heifers and cows (as
Table 1. Prevalence of bovine brucellosis per State in Brazil

\begin{tabular}{|c|c|c|c|}
\hline State & $\begin{array}{l}\text { Farm preva- } \\
\text { lence }(\%)^{*}\end{array}$ & $\begin{array}{l}\text { Seroposi- } \\
\text { tive preva- } \\
\text { lence }(\%)^{*}\end{array}$ & Reference \\
\hline Acre & NA & NA & - \\
\hline Alagoas & NA & NA & - \\
\hline Amapá & NA & NA & - \\
\hline Amazonas & NA & NA & - \\
\hline Bahia & 4.20 & 0.66 & Alves et al. (2009) \\
\hline Ceará & NA & NA & - \\
\hline Distrito Federal & 2.52 & 0.16 & Gonçalves et al. (2009a) \\
\hline Espírito Santo & 9.00 & 3.53 & Azevedo et al. (2009) \\
\hline Goiás & 17.54 & 3.01 & Rocha et al. (2009) \\
\hline Maranhão & NA & NA & - \\
\hline Mato Grosso & 41.20 & 10.20 & Negreiros et al. (2009) \\
\hline Mato Grosso do Sul & 41.50 & 7.93 & Chate et al. (2009) \\
\hline Minas Gerais & 6.04 & 1.09 & Gonçalves et al. (2009b) \\
\hline Pará & ND & 10.92 & Minervino et al. (2011) \\
\hline Paraíba & NA & NA & - \\
\hline Paraná & 4.02 & 1.73 & Dias et al, (2009a) \\
\hline Pernambuco & NA & NA & - \\
\hline Piauí & NA & NA & - \\
\hline Rio de Janeiro & 15.42 & 4.08 & Klein-Gunnewiek et al. (2009) \\
\hline Rio Grande do Norte & NA & NA & - \\
\hline Rio Grande do Sul & 2.06 & 1.02 & Marvulo et al. (2009) \\
\hline Rondônia & 35.18 & 6.22 & Villar et al. (2009) \\
\hline Roraima & NA & NA & - \\
\hline Santa Catarina & 0.32 & 0.06 & Sikusawa et al. (2009) \\
\hline São Paulo & 9.70 & 3.81 & Dias et al. (2009b) \\
\hline Sergipe & 12.60 & 3.36 & Silva et al. (2009) \\
\hline Tocantins & 21.22 & 4.43 & Ogata et al. (2009) \\
\hline
\end{tabular}

* NA = not available, $\mathrm{ND}=$ not determined.

Table 2. Cattle population in Brazil per State and selected categories

\begin{tabular}{|c|c|c|c|c|c|}
\hline \multirow[t]{2}{*}{ State } & \multirow[t]{2}{*}{$\begin{array}{l}\text { Cattle po- } \\
\text { pulation* }\end{array}$} & \multirow[t]{2}{*}{$\begin{array}{l}\text { Milking } \\
\text { cows }\end{array}$} & \multicolumn{3}{|c|}{$\begin{array}{l}\text { Heifers and cows } \geq 24 \\
\text { months of age }(\%)^{* *}\end{array}$} \\
\hline & & & $\begin{array}{c}\text { All } \\
\text { herds }\end{array}$ & $\begin{array}{c}\text { Beef } \\
\text { cattle }\end{array}$ & $\begin{array}{l}\text { Dairy } \\
\text { cattle }\end{array}$ \\
\hline Acre & $2,549,497$ & 71,376 & 26.82 & 24.62 & 1.81 \\
\hline Alagoas & $1,268,304$ & 154,893 & 15.54 & 8.84 & 6.01 \\
\hline Amapá & 127,499 & 11,295 & 43.30 & 37.97 & 2.51 \\
\hline Amazonas & $1,439,597$ & 126,623 & 22.77 & 18.92 & 2.27 \\
\hline Bahia & $10,667,903$ & $2,104,008$ & 19.89 & 13.93 & 5.10 \\
\hline Ceará & $2,611,712$ & 549,897 & 12.03 & 3.67 & 7.88 \\
\hline Distrito Federal & 98,000 & 19,500 & 25.40 & 16.21 & 8.74 \\
\hline Espírito Santo & $2,223,262$ & 408,545 & 23.49 & 10.40 & 12.79 \\
\hline Goiás & $21,744,650$ & $2,615,611$ & 30.75 & 21.09 & 8.69 \\
\hline Maranhão & $7,264,106$ & 591,945 & 24.59 & 19.27 & 3.09 \\
\hline Mato Grosso & $29,265,718$ & 633,782 & 32.25 & 28.61 & 2.58 \\
\hline Mato Grosso do Sul & $21,553,851$ & 530,463 & 31.44 & 29.74 & 1.22 \\
\hline Minas Gerais & $23,907,915$ & $5,631,067$ & 24.52 & 11.41 & 12.78 \\
\hline Pará & $18,262,547$ & 795,268 & 30.13 & 23.24 & 4.43 \\
\hline Paraíba & $1,354,268$ & 259,283 & 12.14 & 6.10 & 5.39 \\
\hline Paraná & $9,461,856$ & $1,588,638$ & 20.59 & 16.33 & 3.91 \\
\hline Pernambuco & $2,502,156$ & 619,919 & 11.15 & 4.62 & 5.77 \\
\hline Piauí & $1,688,024$ & 156,232 & 16.64 & 13.10 & 2.17 \\
\hline Rio de Janeiro & $2,178,896$ & 427,278 & 24.02 & 11.64 & 12.10 \\
\hline Rio Grande do Norte & $1,047,797$ & 262,489 & 15.03 & 6.74 & 7.53 \\
\hline Rio Grande do Sul & $14,478,312$ & $1,530,014$ & 25.73 & 24.15 & 1.11 \\
\hline Rondônia & $12,182,259$ & 989,643 & 30.09 & 19.27 & 10.50 \\
\hline Roraima & 651,511 & 22,707 & 29.50 & 17.83 & 1.95 \\
\hline Santa Catarina & $4,039,217$ & $1,021,605$ & 12.83 & 9.92 & 2.72 \\
\hline São Paulo & $11,024,796$ & $1,452,770$ & 23.77 & 17.71 & 5.54 \\
\hline Sergipe & $1,178,771$ & 226,927 & 14.99 & 9.34 & 4.80 \\
\hline Tocantins & $8,025,400$ & 425,443 & 33.00 & 25.79 & 3.40 \\
\hline Total & $212,797,824$ & $23,227,221$ & 26.62 & 20.18 & 5.48 \\
\hline
\end{tabular}

* Estimated cattle population for 2011. ** Proportions based on the census of 2006 . 
observed in the study by Minervino et al. 2011), an average bull/ cow ratio of $1 / 25$, and same approach for calculating replacement costs as calculated for females (item vi). Costs associated with veterinary assistance were calculated based on a previous study performed under field conditions in Brazil (Lucas 2006). Importantly, since this study is aimed to estimate losses, but not total cost of bovine brucellosis, in spite of its social importance, costs associated with human health were not considered as well as the costs of the Brazilian National Program for Control and Eradication of Brucellosis and Tuberculosis.

Except when stated otherwise, all estimated costs for dairy cattle were based on values previously reported by Lucas (2006), whereas estimated costs for beef cattle were based on Jorge Jr et al. (2006). Reference values were updated based on current market values of milk and meat for dairy and beef cattle, respectively, which were based on values reported by the Centro de Estudos Avançados em Economia Aplicada (CEPEA/ESALQ 2013) for the month of January 2013. Estimated costs of each parameter are detailed in Table 3.

Table 3. Current estimated costs for each productive parameter for dairy or beef cattle

\begin{tabular}{|c|c|c|c|c|}
\hline \multirow[t]{2}{*}{ Parameter } & \multicolumn{2}{|c|}{ Dairy cattle } & \multicolumn{2}{|c|}{ Beef cattle } \\
\hline & $\begin{array}{c}\text { Milk } \\
\text { (liters) }\end{array}$ & $\begin{array}{l}\text { Reais } \\
\text { (R\$) }\end{array}$ & @ steer & $\begin{array}{l}\text { Reais } \\
\text { (R\$) }\end{array}$ \\
\hline $\begin{array}{l}\text { Cost of abortion or perinatal mor- } \\
\text { tality (unit) }\end{array}$ & 366.44 & 323,53 & 1.54 & 150,50 \\
\hline $\begin{array}{l}\text { Cost of temporary infertility (per } \\
\text { seropositive cow) }\end{array}$ & 4.01 & 3,54 & 0.18 & 17,59 \\
\hline Cost of Replacement of cows (unit) & 815.43 & 719,94 & 6.18 & 603,97 \\
\hline Cost of Replacement of bulls (unit)* & $1,223.14$ & $1.079,91$ & 9.27 & 905,95 \\
\hline Mortality of seropositive cattle (unit) & $2,753.64$ & $2.431,18$ & 11.32 & $1.106,30$ \\
\hline $\begin{array}{l}\text { Veterinary costs (per seropositive } \\
\text { cow) }\end{array}$ & 5.54 & 4,89 & 0.043 & 4,20 \\
\hline $\begin{array}{l}\text { Milk production loss (per seropo- } \\
\text { sitive cow) }\end{array}$ & 223.85 & 197,57 & - & - \\
\hline Meat production loss (per seropo- & - & - & 0.58 & 56,68 \\
\hline
\end{tabular}

* Due highly variable market values, the cost for replacing bulls was estimated as $150 \%$ of the cost of replacement of cows. Sources: modified from Lucas (2006); Jorge Jr et al. (2006); Centro de Estudos Avançados em Economia Aplicada (CEPEA, USP/ESALQ <http://cepea.esalq.usp. br>); and IBGE (2011).

\section{Model}

Economic losses were calculated for dairy (ELDC) and beef cattle (ELBC) for each Brazilian State for which comprehensive epidemiological data was available (Poester et al. 2009), according to the following formula:

$$
\text { ELDC }=\mathrm{Ab}_{\mathrm{d}}+\mathrm{Pm}_{\mathrm{d}}+\mathrm{Ti}_{\mathrm{d}}+\mathrm{Rc}_{\mathrm{d}}+\mathrm{Rb}_{\mathrm{d}}+\mathrm{Mt}_{\mathrm{d}}+\mathrm{Vc}_{\mathrm{d}}+\mathrm{M}
$$

Where:

$A b_{d}$ is the cost of abortion in dairy cattle $\left(A b_{d}=\right.$ number of dairy females with age above 24 months X prevalence X 0.15 X 323.53);

$\mathrm{Pm}_{d}$ is the cost of perinatal mortality in dairy cattle $\left(\mathrm{Pm}_{\mathrm{d}}=\right.$ number of dairy females with age above 24 months $\mathrm{X}$ prevalence $\mathrm{X} 0.10 \mathrm{X}$ 323.53);

$\mathrm{Ti}_{\mathrm{d}}$ is the cost of temporary infertility in dairy cattle $\left(\mathrm{Ti}_{\mathrm{d}}=\right.$ number of dairy females with age above 24 months X prevalence $X 3.54$ );

$R c_{d}$ is the cost of replacement of dairy cows $\left(R c_{d}=\right.$ number of dairy females with age above 24 months X prevalence X 0.15 X 719.94); $\mathrm{Rb}_{\mathrm{d}}$ is the cost of replacement of bulls $\left(\mathrm{Rb}_{\mathrm{d}}=\right.$ number of dairy females with age above 24 months $X 1 / 2$ prevalence $X 1 / 25$ X 1079.91); $\mathrm{Mt}_{\mathrm{d}}$ is the cost due to mortality of seropositive dairy cows $\left(\mathrm{Mt}_{\mathrm{d}}=\right.$ number of dairy females with age above 24 months X prevalence X $0.15 \mathrm{X}$ $0.01 \times 2431.18$ );
$\mathrm{Vc}_{\mathrm{d}}$ is the veterinary costs $\left(\mathrm{Vc}_{\mathrm{d}}=\right.$ number of dairy females with age above 24 months X prevalence X 4.89);

$\mathrm{M}$ is milk production loss $(\mathrm{M}=$ State annual milk production [according to IBGE, 2011] X prevalence X 0.15 X 0.8829).

$\mathrm{ELBC}=\mathrm{Ab}_{\mathrm{b}}+\mathrm{Pm}_{\mathrm{b}}+\mathrm{Ti}_{\mathrm{b}}+\mathrm{Rc}_{\mathrm{b}}+\mathrm{Rb}_{\mathrm{b}}+\mathrm{Mt}_{\mathrm{b}}+\mathrm{Vc}_{\mathrm{b}}+\mathrm{Me}$

Where:

$A b_{b}$ is the cost of abortion in beef cattle $\left(A b_{b}=\right.$ number of beef females with age above 24 months $X$ prevalence $X 0.15$ X 150.5);

$\mathrm{Pm}_{b}$ is the cost of perinatal mortality in beef cattle $\left(\mathrm{Pm}_{\mathrm{b}}=\right.$ number of beef females with age above 24 months $X$ prevalence $X 0.10 \mathrm{X} 150.5$ ); $\mathrm{Ti}_{\mathrm{b}}$ is the cost of temporary infertility in beef cattle $\left(\mathrm{Ti}_{\mathrm{b}}=\right.$ number of beef females with age above 24 months $X$ prevalence $X$ 17.59);

$\mathrm{Rc}_{\mathrm{b}}$ is the cost of replacement of beef cows $\left(\mathrm{Rc}_{\mathrm{b}}=\right.$ number of beef females with age above 24 months X prevalence X 0.15 X 603.97); $\mathrm{Rb}_{\mathrm{b}}$ is the cost of replacement of bulls $\left(\mathrm{Rb}_{\mathrm{b}}=\right.$ number of beef females with age above 24 months X $1 / 2$ prevalence X 1/25 X 905.95);

$\mathrm{Mt}_{\mathrm{d}}$ is the cost due to mortality of seropositive beef cows $\left(\mathrm{Mt}_{\mathrm{d}}=\right.$ number of beef females with age above 24 months X prevalence X $0.15 \mathrm{X}$ 0.01 X 1106.30);

$\mathrm{Vc}_{\mathrm{d}}$ is the veterinary costs $\left(\mathrm{Vc}_{\mathrm{d}}=\right.$ number of beef females with age above 24 months $X$ prevalence $X$ 4.20);

Me is meat production loss $(\mathrm{Me}=$ number of beef females with age above 24 months X prevalence X 56.68).

Linear regression analysis was performed using the GraphPad Instat software version 3.10.

\section{RESULTS}

Each infected cow represent an estimate loss of $R \$ 420,12$ or $\mathrm{R} \$ 226,47$ in case of dairy or beef cattle, respectively. Total estimated losses in Brazil were estimated to be approxi-

Table 4. Estimated economic losses in dairy and beef cattle in Brazilian states with comprehensive epidemiological data available*

\begin{tabular}{lccc}
\hline \multicolumn{1}{c}{ State } & Dairy cattle & Beef cattle & Total \\
\hline Bahia & $1.868 .296,94$ & $2.321 .192,53$ & $4.189 .489,48$ \\
Distrito Federal & $9.463,17$ & $5.859,48$ & $15.322,65$ \\
Espírito Santo & $4.373 .472,08$ & $1.872 .869,21$ & $6.246 .341,29$ \\
Goiás & $26.953 .925,30$ & $32.282 .555,22$ & $59.236 .480,52$ \\
Mato Grosso & $27.784 .600,37$ & $199.964 .995,36$ & $227.749 .595,73$ \\
Mato Grosso do Sul & $10.228 .498,61$ & $116.873 .082,42$ & $127.101 .581,03$ \\
Minas Gerais & $20.152 .144,28$ & $6.826 .750,96$ & $26.978 .895,24$ \\
Pará & $29.961 .048,03$ & $114.314 .497,85$ & $144.275 .545,87$ \\
Paraná & $10.200 .340,57$ & $6.158 .942,21$ & $16.359 .282,78$ \\
Rio de Janeiro & $5.122 .400,89$ & $2.371 .200,97$ & $7.493 .601,86$ \\
Rio Grande do Sul & $5.614 .626,90$ & $8.226 .209,53$ & $13.840 .836,44$ \\
Rondônia & $23.718 .015,07$ & $33.425 .186,43$ & $57.143 .201,49$ \\
Santa Catarina & $216.062,40$ & $55.274,52$ & $271.336,91$ \\
São Paulo & $13.375 .114,77$ & $17.227 .857,21$ & $30.602 .971,98$ \\
Sergipe & $1.855 .085,13$ & $888.414,13$ & $2.743 .499,26$ \\
Tocantins & $4.610 .792,96$ & $23.473 .875,24$ & $28.084 .668,20$ \\
Total & $186.043 .887,48$ & $566.288 .763,25$ & $752.332 .650,73$ \\
Estimated losses in the & $42.436 .663,87$ & $97.947 .198,40$ & $140.383 .862,27$ \\
remaining States** & & & \\
Estimatedtotalosses & $228.480 .551,35$ & $664.235 .961,65$ & $892.716 .513,00$
\end{tabular}

Estimated total losses $228.480 .551,35 \quad 664.235 .961,65 \quad 892.716 .513,00$ in Brazil ${ }^{* * *}$

* Values are expressed in Reais (R\$), with one American dollar corresponding to $\mathrm{R} \$ 1,99$ (exchange rate of January $31^{\text {st }}, 2013$ ). ${ }^{* *}$ Ponderated average prevalence was applied to cattle population of the remaining states (Acre, Alagoas, Amapá, Amazonas, Ceará, Maranhão, Paraíba, Pernambuco, Piauí, Rio Grande do Norte, and Roraima) considering the proportion of dairy and beef cattle in these states. ${ }^{* *}$ Values adjusted to the remaining States (that do not have comprehensive epidemiological data available) that collectively have $10.57 \%$ of the Brazilian cattle population. 
mately R\$ 892 million (about US\$ 448 million), which corresponds to $0.3201 \%$ of the 2011 Brazilian GDP referring to animal production or $0.0215 \%$ of the 2011 National GDP. Economic losses per state and activity (i.e. dairy or beef cattle) are detailed in Table 4. Total losses and the percentage of loss of the agribusiness GDP per state are illustrated in Figures 1 and 2, respectively. The impact of different com-

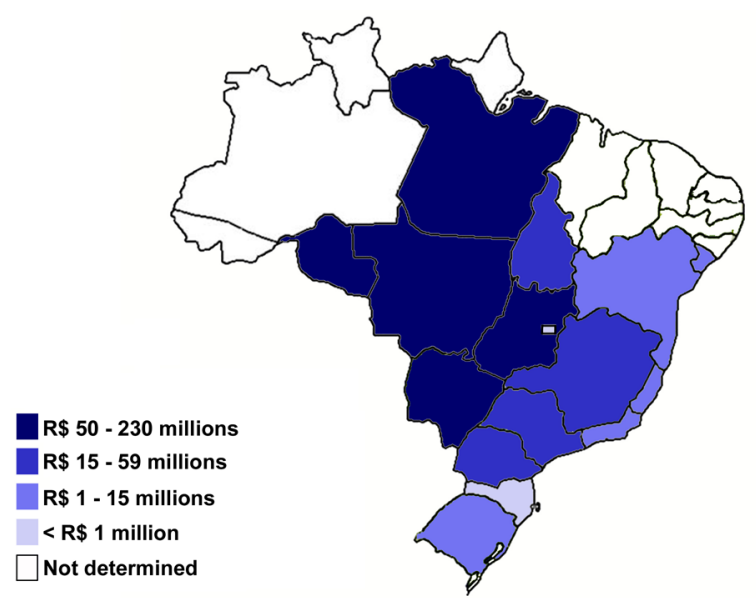

Fig.1. Total estimated economic losses due to bovine brucellosis per state in Brazil.

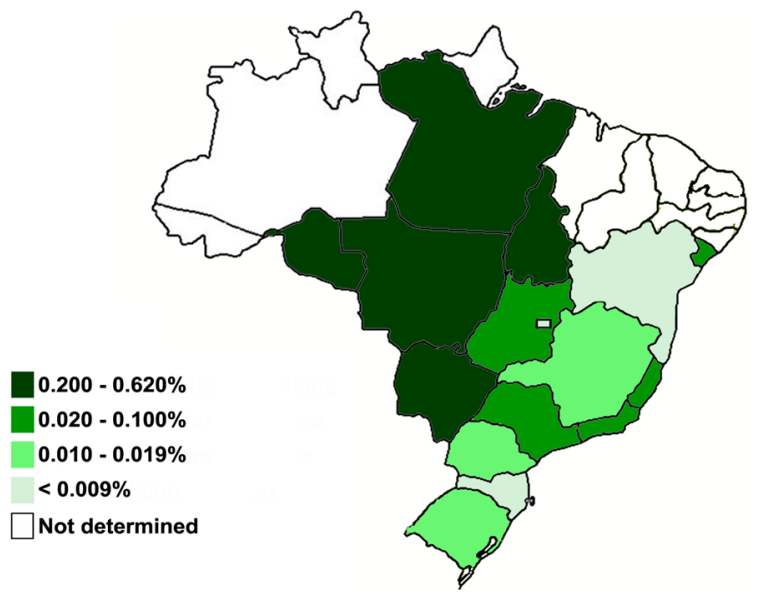

Fig.2. Percentage of losses of the agribusiness Gross Domestic Product (GDP) due to bovine brucellosis per state in Brazil.

ponents of cost varied among states, which was strongly influenced by both the prevalence of bovine brucellosis and the ratio between dairy and beef cattle (Fig.3).

Considering the total cattle population in each of the states where epidemiological data were available, a linear regression analysis to predict economic losses as a function of prevalence, resulted in the following best fitted model: [Losses per head $(\mathrm{R} \$)=0.1864+0.7281 \mathrm{x}$ Prevalence (\%)]; which has a slope that is statistically significantly different from zero $(\mathrm{P}<0.0001)$. This analysis indicates that a one percent increase in prevalence results in roughly an additional loss of $\mathrm{R} \$ 0.73$ (seventy three cents of Reais or 0.37 cents of American dollars) per head of cattle in Brazil (Fig.4), which considering the estimated current cattle population in Brazil (Table 2), would result in an additional

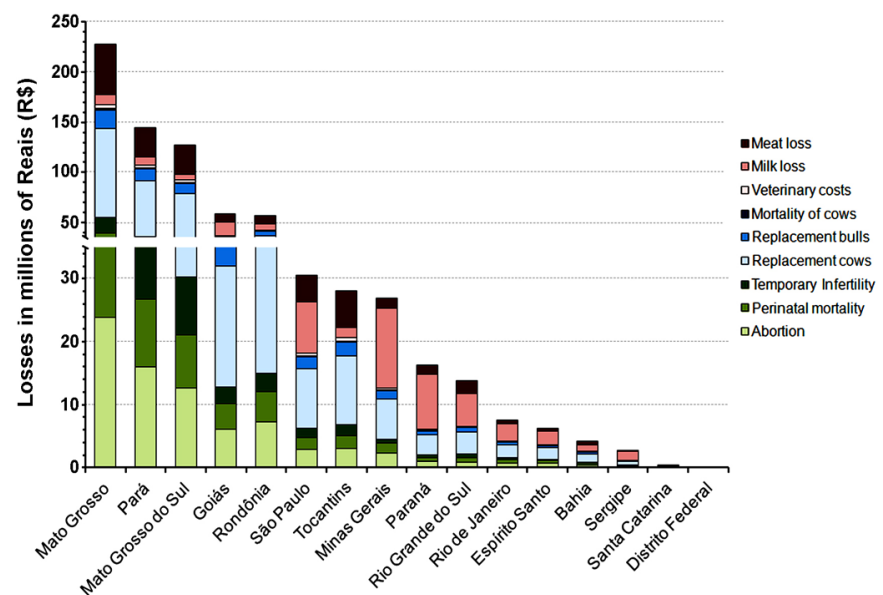

Fig.3. Composition of economic losses due to bovine brucellosis in Brazilian states with available comprehensive epidemiological data (X axis). Different components of economic losses, including abortion, perinatal mortality, temporary infertility, replacement of cows, replacement of bulls, mortality of cows, veterinary costs, milk loss, and meat loss, are indicated.

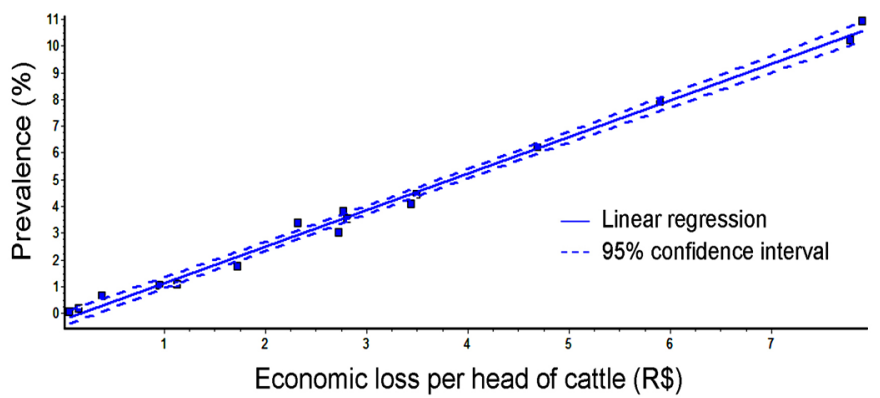

Fig.4. Linear regression model of economic losses as a function of prevalence of bovine brucellosis in Brazil. Solid line indicate the linear regression and the dotted line indicates 95\% confidence interval. Data points refer to each one of 16 states for which comprehensive epidemiological data was available. The slope is significantly different from zero $(\mathrm{P}<0.0001)$.

loss of $\mathrm{R} \$ 154,938,095.65$ for each $1 \%$ increase in prevalence, and obviously proportional economic gain associated with decrease in the prevalence.

\section{DISCUSSION}

This study provided a thorough assessment of economic losses associated with brucellosis in Brazil, indicating a heavy economic burden on the national livestock industry, which is a major component of the national GDP. This study is extremely important since previous studies are restricted to the farm level (Lucas 2006) or are completely outdated (Brasil 1971). These data are highly relevant for establishing public policies for control and eradication programs. Brazil has a National Program for Control and Eradication of Brucellosis and Tuberculosis that among other things has recently provided reliable epidemiological data (Poester et al. 2009) that generated the basic data for this study that resulted in a precise estimate of the economic burden imposed by bovine brucellosis in Brazil. An accurate estimate of economic losses due to bovine brucellosis is strategic for planning destination of financial resources for 
control programs. Importantly, these losses compromise over $0.3 \%$ of the Brazilian GDP fraction generated by animal production, which is highly significant considering that Brazil currently has the largest commercial bovine heard in the world, and the country is a leading beef exporter. Additional parameters for dimensioning the economic impact of bovine brucellosis in Brazil is the fact the total losses of about 892.7 million Reais is roughly equivalent to a little more than one billion liters of milk or more than 500 thousand fattened steers for slaughter.

A comprehensive model was developed in this study, which was based on reliable epidemiological data (Alves et al. 2009, Gonçalves et al. 2009a, 2009b, Azevedo et al. 2009, Rocha et al. 2009, Chate et al. 2009, Negreiros et al. 2009, Dias et al. 2009a, 2009b, Klein-Gunnewiek et al. 2009, Villar et al. 2009, Marvulo et al. 2009, Sikusawa et al. 2009, Silva et al. 2009, Ogata et al. 2009, Minervino et al. 2011), on sound clinical parameters (Bernués et al. 1997), and on scientifically determined economic variables appropriate for dairy (Lucas 2006) or beef cattle (Jorge Jr et al. 2006). This model has an intermediate level of stringency. As previously discussed by Bernués et al. (1997), clinical parameters used in this study (i.e. abortion and perinatal mortality rates, temporary infertility, replacement costs, mortality, veterinary costs, milk and meat losses) are quite conservative when compared to the range previously reported in the literature. The option for electing conservative clinical parameters prevented an overestimation of the actual economic loss.

Losses were strongly influenced by prevalence and production system (i.e. dairy vs. beef cattle). For instance, comparing the states of Minas Gerais and Tocantins, in spite of having strikingly different epidemiological situations, the first with a relatively low prevalence $(1.09 \%)$ and the second with a high prevalence $(4.43 \%)$, they have similar levels of economic losses (26.9 vs. 28.0 million Reais, respectively). Interestingly, composition of losses is predominantly due to milk loss in the case of Minas Gerais, while replacement costs are the major component in the case of Tocantins (Fig.2). These differences reflect the fact that Minas Gerais has 5.6 million milking cows that generates approximately 8.7 billion of litters of milk annually (IBGE 2011), whereas Tocantins has only 0.4 million milking cows, producing 0.2 billion of litters of milk annually. Importantly, although the most important clinical manifestation of bovine brucellosis is abortion and perinatal mortality (Carvalho Neta et al. 2010, Xavier et al. 2009b), losses associated with abortion and perinatal mortality do not correspond to a major fraction of the losses in any of the states studied (Fig.3).

Although we elected to develop a highly comprehensive model for this analysis, the model does not cover all variables that could ultimately be strongly influenced by prevalence of bovine brucellosis. For instance, only the cost of vaccination represents additional several million Reais since in 2011 approximately 11.8 million cattle have been vaccinated in Brazil (OIE 2012). Furthermore, possible human infections due to bovine brucellosis have not been precisely assessed in Brazil, where there are scarce reports of human infections, although it has been clearly identified a significant human health issue among risk occupational groups in Brazil (Ramos et al. 2008) since the country is free of Brucella melitensis, which reduces the risk of human brucellosis (Poester et al. 2002). Although underreported, human brucellosis in Brazil certainly represents an additional economic burden due to medial costs, although and most importantly, human infections have a major social impact due to decreased productivity and quality of life, and occasionally incapacitation or death.

\section{CONCLUSION}

Bovine brucellosis in Brazil results in heavy economic losses to the livestock industry with significant impact on both dairy and beef cattle. These data clearly indicate that appropriate control programs may have an extremely favorable cost/benefit relationship since any decrease in prevalence has a direct effect on the economic burden imposed by the disease. Future studies should address the public health implications of brucellosis.

Acknowledgements.- The investigation in RLS lab was supported by CNPq - Conselho Nacional de Desenvolvimento Científico e Tecnológico, Brasília, FAPEMIG - Fundação de Amparo à Pesquisa do Estado de Minas Gerais, Belo Horizonte, and CAPES/PROEX.

\section{REFERENCES}

Alves A.J.S., Gonçalves V.S.P., Figueiredo V.C.F., Lôbo J.R., Bahiense L., Amaku M., Ferreira F., Ferreira Neto J.S. \& Dias R.A. 2009. Situação epidemiológica da brucelose bovina no Estado da Bahia. Arq. Bras. Med. Vet. Zootec. 61:6-13.

Azevedo S.S., Ferreira Neto J.S., Dias R.A., Ferreira F., Amaku M., Figueiredo V.C.F., Lôbo J.R., Gonçalves V.S.P., Souza A.C. \& Vasconcellos S.A. 2009. Situação epidemiológica da brucelose bovina no Estado do Espírito Santo. Arq. Bras. Med. Vet. Zootec. 61:19-26.

Bernués A., Manrique E. \& Maza M.T. 1997. Economic evaluation of bovine brucellosis and tuberculosis eradication programmes in a mountain area of Spain. Prev. Vet. Med. 30:137-149.

Brasil 1971. Estado atual das campanhas sanitárias: campanha de controle à brucelose. Bolm Def. Sanit. Anim., Min. Agricult., 5:17-26.

Carvalho Neta A.V., Mol J.P.S., Xavier M.N., Paixão T.A., Lage A.P. \& Santos R.L. 2010. Pathogenesis of bovine brucellosis. Vet. J. 184:146-155.

CEPEA/ESALQ 2013. Agromensal. Informações de mercado, Janeiro 2013. Available http://cepea.esalq.usp.br/agromensal/2013/01_janeiro/ Pecuaria.htm Accessed Feb. 20, 2013.

Chate S.C., Dias R.A., Amaku M., Ferreira F., Moraes G.M., Costa Neto A.A., Monteiro L.A.R.C., Lôbo J.R., Figueiredo V.C.F., Gonçalves V.S.P. \& Ferreira Neto J.S. 2009. Situação epidemiológica da brucelose bovina no Estado do Mato Grosso do Sul. Arq. Bras. Med. Vet. Zootec. 61:46-55.

Dias R.A., Gonçalves V.S.P., Figueiredo V.C.F., Lôbo J.R., Lima Z.M.B., Paulin L.M.S., Gunnewiek M.F.K., Amaku M., Ferreira Neto J.S. \& Ferreira F. 2009a. Situação epidemiológica da brucelose bovina no Estado de São Paulo. Arq. Bras. Med. Vet. Zootec. 61:118-125.

Dias J.A., Müller E.E., Dias R.A., Freitas J.C., Amaku M., Ferreira F., Silva M.C.P., Lôbo J.R., Figueiredo V.C.F., Gonçalves V.S.P. \& Ferreira Neto J.S. 2009b. Situação epidemiológica da brucelose bovina no Estado do Paraná. Arq. Bras. Med. Vet. Zootec. 61:66-76.

Gonçalves V.S.P., Ribeiro L.A., Caldas R.A., Francisco P.F.C., Dias R.A., Ferreira F., Amaku M., Ferreira Neto J.S., Figueiredo V.C.F., Lôbo J.R. \& Borges J.R.J. 2009a. Situação epidemiológica da brucelose bovina no Distrito Federal. Arq. Bras. Med. Vet. Zootec. 61:14-18.

Gonçalves V.S.P., Delphino M.K.V.C., Dias R.A., Ferreira F., Amaku M., Ferreira Neto J.S., Porto T.B., Alves C.M., Figueiredo V.C.F. \& Lôbo J.R. 2009b. Si- 
tuação epidemiológica da brucelose bovina no Estado de Minas Gerais. Arq. Bras. Med. Vet. Zootec. 61:35-45.

IBGE 2011. Produção da Pecuária Municipal 2011. Número 39. 60p.

IBGE 2012. Contas Regionais 2010. Número 38. 55p.

Jorge Júnior J., Cardoso V.L. \& Albuquerque L.G. 2006. Modelo bioeconômico para cálculo de custos e receitas em sistemas de produção de gado de corte visando à obtenção de valores econômicos de características produtivas e reprodutivas. Revta Bras. Zootec. 35:2187-2196.

Klein-Gunnewiek M.F.C., Amaku M., Dias R.A., Ferreira F., Gitti C.B., Pereira L.A., Figueiredo V.C.F., Lobo J.R., Gonçalves V.S.P. \& Ferreira Neto J.S. 2009. Situação epidemiológica da brucelose bovina no Estado do Rio de Janeiro. Arq. Bras. Med. Vet. Zootec. 61:77-84.

Lucas A. 2006. Simulação de impacto econômico da brucelose bovina em rebanhos produtores de leite das regiões Centro Oeste, Sudeste e Sul do Brasil. Tese de Doutorado, Universidade de São Paulo, São Paulo, SP, $123 p$.

Marvulo M.F.V., Ferreira F., Dias R.A., Amaku M., Groff A.C.M., Gonçalves V.S.P., Figueiredo V.C.F., Lôbo J.R. \& Ferreira Neto J.S. 2009. Situação epidemiológica da brucelose bovina no Estado do Rio Grande do Sul. Arq. Bras. Med. Vet. Zootec. 61:93-102.

Minervino A.H.H., Calhau A.S., Alves Filho A., Barbosa R.S., Neves K.A.L., Barros I.O., Barreto R.A. \& Ortolani E.L. 2011 Estudo retrospectivo da ocorrência de bovinos soro reagentes à brucelose no estado do Pará. Acta Vet. Bras. 5:47-53.

Negreiros R.L., Dias R.A., Ferreira F., Ferreira Neto J.S., Gonçalves V.S.P., Silva M.C.P., Figueiredo V.C.F., Lôbo J.R., Freitas J. \& Amaku M. 2009. Situação epidemiológica da brucelose bovina no Estado de Mato Grosso. Arq. Bras. Med. Vet. Zootec. 61:56-65.

Ogata R.A., Gonçalves V.S.P., Figueiredo V.C.F., Lôbo J.R., Rodrigues A.L., Amaku M., Ferreira F., Ferreira Neto J.S. \& Dias R.A. 2009. Situação epidemiológica da brucelose bovina no Estado do Tocantins. Arq. Bras. Med. Vet. Zootec. 61:126-134.

OIE 2012. Annual animal health report on the notification of the absence or presence of all diseases. OIE Reference: 134031, 131583, 116901, Report Period: Jan.-Dec. 2011. Country: Brazil.

Poester F., Figueiredo V.C.F., Lôbo J.R., Gonçalves V.S.P., Lage A.P., Roxo E.,
Mota P.M.P.C., Müller E.E. \& Ferreira Neto J.S. 2009. Estudos de prevalência da brucelose bovina no âmbito do Programa Nacional de Controle e Erradicação de Brucelose e Tuberculose: Introdução. Arq. Bras. Med. Vet. Zootec. 61:1-5.

Poester F., Gonçalves V.S.P. \& Lage A.P. 2002. Brucellosis in Brazil. Vet. Microbiol. 90:55-62.

Poester F.P., Samartino L.E. \& Santos R.L. 2013. Pathogenesis and pathobiology of brucellosis in livestock. Rev. Sci. Tech. - OIE. (In publication)

Ramos T.R., Pinheiro Junior J.W., Moura Sobrinho P.A., Santana V.L., Guerra N.R., Melo L.E. \& Mota R.A. 2008. Epidemiological aspects of an infection by Brucella abortus in risk occupational groups in the microregion of Araguaína, Tocantins. Braz. J. Infect. Dis. 12:133-138.

Rocha W.V., Gonçalves V.S.P., Coelho C.G.N.F.L., Brito W.M.E.D., Dias R.A., Delphino M.K.V.C., Ferreira F., Amaku M., Ferreira Neto J.S., Figueiredo V.C.F., Lôbo J.R. \& Brito L.A.B. 2009. Situação epidemiológica da brucelose bovina no Estado de Goiás. Arq. Bras. Med. Vet. Zootec. 61:27-34.

Sikusawa S., Amaku M., Dias R.A., Ferreira Neto J.S., Martins C., Gonçalves V.S.P., Figueiredo V.C.F., Lôbo J.R. \& Ferreira F. 2009. Situação epidemiológica da brucelose bovina no Estado de Santa Catarina. Arq. Bras. Med. Vet. Zootec. 61:103-108.

Silva V.G.S.O., Dias R.A., Ferreira F., Amaku M., Costa E.L.S., Lôbo J.R., Figueiredo V.C.F., Gonçalves V.S.P. \& Ferreira Neto J.S. 2009. Situação epidemiológica da brucelose bovina no Estado de Sergipe. Arq. Bras. Med. Vet. Zootec. 61:109-117.

Villar K.S., Amaku M., Dias R.A., Ferreira Neto J.S., Benitez F., Gonçalves V.S.P., Figueiredo V.C.F., Lôbo J.R. \& Ferreira F. 2009. Situação epidemiológica da brucelose bovina no Estado de Rondônia. Arq. Bras. Med. Vet. Zootec. 61:85-92.

Xavier M.N., Costa E.A., Paixão T.A. \& Santos R.L. 2009a. The genus Brucella and clinical manifestations of brucellosis. Ciência Rural 39:2252-2260.

Xavier M.N., Paixão T.A., Poester F.P., Lage A.P. \& Santos R.L. 2009b. Pathological, immunohistochemical, and bacteriological study of tissues and milk of cows and fetuses experimentally infected with Brucella abortus. J. Comp. Pathol. 140:147-157.

Young E.J. 1995. An overview of human brucellosis. Clin. Infect. Dis. 21:283-289. 